\title{
The role of retinoids in acute renal damage associated with acetic acid induced ulcerative colitis in adult male rats : Histological and biochemical study
}

\author{
Original \\ Dalia A. Mohamed ${ }^{1,2}$,Samah M. Ahmed ${ }^{1}$ and Manal M. Kamal ${ }^{3,4}$ \\ Article \\ ${ }^{1}$ Department of Histology and Cell Biology, Faculty of Medicine, Zagazig University, Zagazig, \\ Egypt, ${ }^{2}$ Department of Histology, College of Medicine, Qassim University, Saudi Arabia, \\ ${ }^{3}$ Department of Medical Physiology, Faculty of Medicine, Assiut University, Asssiut, Egypt, \\ ${ }^{4}$ Department of Physiology, College of Medicine, Qassim University, Saudi Arabia.
}

\begin{abstract}
Background: Ulcerative colitis (UC) is a chronic inflammatory disease of the colon. However, it affects other extra-intestinal organs, such as the kidney.

Objective: This study aimed to demonstrate the histological changes of renal cortex associated with acetic acid (AA) induced colitis and to evaluate the role of retinoids in colitis and its mediated renal injury.

Materials and Methods: 42 adult male rats were divided into: group I (control), group II (AA- colitis) received acetic acid (AA) rectal enema, group III received retinyle palmitae (RP- treated) and group IV treated with all-trans retinoic acid (ATRAtreated) after colitis induction. For biochemical analysis, colon and kidney tissue levels of tumor necrosis factor-alpha (TNF- $\alpha$ ), nuclear factor kappa-B (NF-кB), vascular endothelial growth factor-A (VEGF-A), myeloperoxidase (MPO), malondialdehyde (MDA), total nitrite and total antioxidant capacity (TAC) were aasessed. Also, sections of the renal cortex were taken for histolopathological evaluation and immunohistochemical detection of BAX.

Results: AA-induced Colitis induced acute injury in renal cortex of animals. Both RP and ATRA showed a significant ameliorating effect on colitis and colitis-associated acute kidney injury, reduced weight loss, decreased colon and kidney neutrophil infiltration, NF- $\kappa$ B, TNF- $\alpha$ and MPO levels, with decline in VEGF-A, MDA, total nitrite and elevated TAC. Both groups had less renal tissue damage and decrease tubules apoptosis.

Conclusion: Both retinoids are effective mostly ATRA in amelioration of the inflammatory process in colitis and its histological renal impaction. This response may be attributed to their anti-inflammatory mechanism by inhibiting NF- $\mathrm{B}$ and reducing tissue alterations via their antioxidant and antiangiogenic properties.
\end{abstract}

Key Words: Acute kidney injury, antioxidants, apoptosis; NF-kappa B, rats, retinoids, ulcerative colitis.

Revised: 10 March 2019, Accepted: 11 July 2019

Corresponding Author: Dalia A Mohamed, Ph.D, Department of Histology and Cell Biology, Faculty of Medicine, Zagazig University, Zagazig, Egypt, Tel.: +201223168887, E-mail: daliafarag@gmail.com, daliafarag@qumed.edu.sa

ISSN:2536-9172, June 2019, Vol. 3, No. 1

\section{INTRODUCTION}

Ulcerative colitis (UC) is a subtype of inflammatory bowel disease (IBD) with chronic, relapsing inflammation of the colon and rectum leads to mucosal ulceration and tissue damage ${ }^{[1]}$. This disorder is characterized by alternating episodes of exacerbations and remission of abdominal pain, frequent bouts of bloody diarrhea and other systemic manifestation ${ }^{[2]}$.

In UC, various extra-intestinal manifestation occur involving many systems that contribute to its morbidity and mortality ${ }^{[3]}$. Renal involvement in patients with UC frequently encountered and included renal stones, ureteral obstruction and tubular injury. Several studies postulated different underling mechanisms that induced kidney involvement with UC. These mechanisms include autoimmune mechanisms, electrolyte imbalance and extensive use of drugs to control the disease and/or maintain remission ${ }^{[4,5,6]}$.

There is available data that described renal involvement mostly in long-standing disease. However, the renal damage is scarce in early course of disease before the start of drug. One study reported tubular proteinuria as a nonintestinal manifestation of IBD irrespective of therapy ${ }^{[7]}$. Another study acknowledged overt renal failure unrelated to nephrotoxic drugs administration, assuming that renal impairment is attributed to the pathophysiological process of the UC itself and recommending that clinicians should evaluate its kidney complications ${ }^{[8]}$.

Although the pathophysiology of UC and extra- 
intestinal manifestation is complex and remains unclear, recent researches proposed that intestinal pathology could result from dysfunction of the intestinal immune system with aggressive immune activation, in genetically susceptible individuals ${ }^{[9,10]}$. A cardinal feature of UC is the massive colonic leukocyte infiltration with production of cytokines, angiogenic growth factors, proteolytic enzymes and oxidants. All these factors share in disease initiation, tissue damage, impairing intestinal barrier with induction of systemic inflammatory response among other organs ${ }^{[11]}$.

The role of inflammation in colitis-induced kidney injury remains to be explored and effectively controlled. The use of anti-inflammatory agents as the first therapeutic approach to control UC and to maintain remission is associated with frequent adverse events on the kidney. Other currently used therapeutic approaches are less satisfactory so far ${ }^{[5]}$. Therefore, there is an urgent need for novel therapeutic agents, particularly to control the exaggerated inflammation within the intestine and the associated kidney damage as well.

Retinoids are important derivatives of vitamin A (VA) that have several cellular functions including cell differentiation, inhibition of proliferation, regulation of apoptosis, and suppression of inflammation. Retinoid also has other physiological roles as regulation of immune responses, antioxidant and anticancer functions in various systems $^{[12,13]}$.

Furthermore, VA and retinoic acid, the principal metabolite of VA, are reported to have benefit effect on intestinal diseases, for instance, mice deprived of VA resulted in exacerbated experimental colitis than in retinyl acetate supplemented ${ }^{[14]}$. In addition, retinoic acid supplementation efficiently decreases the severity of inflammation in a mouse model of ileitis ${ }^{[15]}$. Confirmatory experimental study reported that retinoid alleviate a variety of renal diseases in animal models. In Adriamycin-induced podocytes injury, retinoic acid induced new differentiation in injured podocytes ${ }^{[16]}$. Also,treatment with retinoic acid significantly reduces the development of renal damage in rats with early diabetic nephropathy ${ }^{[17]}$.

Hence, the present study was designed to assess the impact of acetic acid-induced colitis on renal cortex during early colonic inflammation and to determine the pathophysiological and histological renal alterations at initial stages. Additionally, it investigated whether retinyle palmitate (RP) the nutrient form or all-trans retinoic acid (ATRA) the metabolic form of retinoid can attenuate intestinal disease and the development of kidney injury and the possible underlying mechanisms for their effects, aiming to find better therapeutic approaches for the treatment of UC and colitis-related kidney diseases.

\section{MATERIALS AND METHODS}

\section{Drugs and chemicals:}

Acetic acid (AA) (94\% concentration, ready-made, VACSERA, Egypt) was diluted with normal saline to obtain concenteration of $4 \%$ AA.

All-trans retinoic acid (ATRA) was purchased from Sigma Chemical Company, USA (98\% purity) as powder, it was dissolved in buffered saline, stored in light protected vials at $-20^{\circ} \mathrm{C}$.

Retinyle palmitate (RP) (Vitamin A palmitae, 25,000 IU with $7.5 \mathrm{mg}$ VA) was obtained from Pharco Pharmaceuticals Industries, Alexandria, Egypt.

\section{Animals:}

Forty-two adult male albino rats (13-16 weeks old), with an average weight of 200-250 g were used in this study. They were locally bred at the animal house at Faculty of Medicine, Zagazig University, Egypt. The animals were housed at controlled room temperature $(25 \pm 2 \circ \mathrm{C})$, and humidity (60-70\%). They had access to chow diet and water ad libitum, kept under a natural 12 light/12 dark cycle. Animals were given two weeks acclimatization period before starting the experiment. The study protocol was approved by the Ethics Committee according to (Ethical Guidelines of Experiments on Animals), Faculty of Medicine, Zagazig University, Egypt; all efforts to prevent animal sufferings were taken.

\section{Induction of $U C$ :}

Acetic acid was used to induce colitis in this experiment because it induced colitis that simulated human UC in mediator release, histological changes, leucocyte infiltration and effectiveness of drugs ${ }^{[18]}$. The animals were fasted for $24 \mathrm{~h}$ but access to water ad libitum only. Then, they were anaesthetized with $50 \mathrm{mg} / \mathrm{kg}$ sodium pentobarbital before UC induction. Then, $1 \mathrm{ml}$ of $4 \%(\mathrm{v} / \mathrm{v})$ AA in normal saline was slowly instilled into colon 8 $\mathrm{cm}$ proximal to anal verge, followed by $2 \mathrm{ml}$ of air using soft pediatric catheter ( $2 \mathrm{~mm}$ diameter) for $30 \mathrm{~s}$. The air injected in the tube to completely eject AA into colon. Rats were kept in head down position during instillation and 1 min after it to prevent leakage of solution out ${ }^{[19]}$. Control rats were given intracolonic $1 \mathrm{ml}$ normal saline with the same procedures.

\section{Experimental design:}

The animals were randomly divided into the following groups: 
Group I (control): ( $\mathrm{n}=18)$ Rats underwent the same procedure of induction of colitis by administration of $1 \mathrm{ml}$ saline in the colon and divided into 3 subgroups (6 rats each); negative control (Ia) : didn't receive any treatment.

Vehicle 1 control $(\mathrm{Ib})$ : received $0.25 \mathrm{~mL}$ corn oil given orally.

Vehicle 2 control (Ic): received daily i.p injection of saline vehicle.

Group II (AA-induced colitis) $(\mathrm{n}=12)$ : Rats received rectal administration of $1 \mathrm{ml}$ AA (4\%) through enema instillation for colitis induction as discussed.

Group III (RP-treated) $(\mathrm{n}=6)$ : were treated with RP $1 \mathrm{mg}$ daily dissolved in $0.25 \mathrm{~mL}$ corn oil given orally ${ }^{[20]}$ via a metallic gastric tube started $2 \mathrm{~h}$ after rectal administration of $1 \mathrm{ml}(4 \%)$ AA.

Group IV (ATRA-treated) $(n=6)$ : were treated with i.p. injection of ATRA, dose $15 \mathrm{mg} / \mathrm{kg}$ (modified from Bai et al. ${ }^{[21]}$, after estimation of rat equivalent dose) started $2 \mathrm{~h}$ after rectal administration of $1 \mathrm{ml}(4 \%)$ AA. ATRA was dissolved in buffered saline, diluted immediately before injection in sterile phosphate-buffered saline. All treatments repeated daily until the rats were sacrificed on day 15.

\section{Tissue and blood samples collection:}

Twenty-four hours after the last treatments rats were anaesthetized with light ether and blood samples were collected by direct heart puncture. Then animals were euthanized by cervical dislocation. A midline laparatomy was immediately performed and about $10 \mathrm{~cm}$ of distal colons were excised out, dissected from fat and mesentery washed with normal saline and blotted on filter paper. The length and weight of the colon were measured; the colonic wet weight/length ratio was calculated. Colon samples $(5-6 \mathrm{~cm})$ longitudinally split and used for macroscopic assessment of colitis.

Parts of the colon and renal cortex specimens were immediately taken and fixed in $10 \%$ formol saline, and processed for histological examination. The remaining portions were homogenized in ice-cold phosphate buffer saline centrifuged at $3000 \mathrm{rpm}$ for $15 \mathrm{~min}$, and the supernatants were stored at $-20^{\circ} \mathrm{C}$ until used. Blood samples centrifuged for $20 \mathrm{~min}$ at $3000 \mathrm{rpm}$. The serum fraction of blood was extracted and preserved at $-80^{\circ} \mathrm{C}$ until used.

Measured parameters:

\section{- Disease activity index (DAI):}

Rats were isolated in different cages to detect score ranging from 0 (healthy) to 12 (severe colitis). This was calculated according to cooper et al. ${ }^{[22]}$, by evaluating the percentage loss of body weight (0-4), consistency of stool $(0-4)$, and presence of rectal bleeding (0-4).

\section{- Macroscopic assessment of colon damage:}

The colon macroscopic damage from $0-10$ scale was evaluated based on the criteria of Tsune et al. ${ }^{[23]}$ according to clinical appearance of the colon, severity inflammation and ulceration.

\section{Histological (microscopic) examination:}

Colon examination: Full thickness colon biopsy specimens processed to obtain paraffin section slides that were stained with H\&E for light microscope examination.

Kidney examination: Specimens of renal cortex were taken and rapidly fixed, processed and embedded to obtain paraffin blocks and cut at 5-6 micron thickness sections. Then, sections were subjected to the following stains ${ }^{[24]}$ :

- Routine Haematoxylin and Eosin (H \&E) stain.

- Mallory trichrome stain to show the collagen fibers and assess fibrosis.

- Immunohistochemical stain for Bax protein to assess apoptosis.

\section{- Immunohistochemistery detection of Bax protein in kidney:}

Paraffin sections were put in xylene, hydrated, and treated with $3 \%$ hydrogen peroxide. Sections were incubated with a monoclonal antibody against Bax (Dako, Carpinteria CA, USA). Detection of the antibody was performed using a biotin- streptavidin detection system with 3-amino 9-ethyl carbazole (AEC) as chromogen (Dako, Carpinteria CA, USA) for Bax. Negative control sections were treated according to the protocol, omitting exposure to primary antibodies.

\section{- Ultrastructural examination for kidney:}

Specimens for electron microscope examination were immediately fixed in $2.5 \%$ glutaraldehyde for 2 hours, and then post fixed in $1 \%$ osmium tetraoxide for another one hour. They were processed to prepare semithin and ultrathin sections using Leica ultra cut (UCT). Semithin sections $(1 \mu \mathrm{m}$ thick) were stained with $1 \%$ toluidine blue for light microscope examination. Ultrathin sections were stained with uranyl acetate and lead citrate and examined with JEOL JEM 1010 electron Microscope, Mansura University ${ }^{[25]}$. 


\section{Biochemical assays:}

\section{- Assessment of kidney function:}

Serum levels of urea, creatinine, were detected by colorimetric methods (Diamond Diagnostics, Egypt).

\section{- Tissues homogenate biochemical assay:}

The tissues (kidney and colon) levels of tumer necrosis factor-alpha (TNF- $\alpha$ ) and nuclear factor kappa-B (NF- $\kappa \mathrm{B})$ were evaluated by commercially available ELISA kits obtained from RayBiotech (Georgia, USA) and Cusabio Technology (China) respectively. Tissue levels of vascular endothelial growth factor-A (VEGF-A) was measured by ELISA method (R\&D Systems, MN, USA). All the procedures were done according to the manufacturer's instructions.

\section{- Assessment of oxidative stress:}

Lipid peroxidation, indicator for oxidative stress was detected by measuring malondialdehyde (MDA) contents in tissue using thiobarbituric acid reactive substance method assay (Lipid Peroxide Assay, BioDiagnosticEgypt $)^{[26]}$. Total nitrite as the final products of nitric oxide in vivo was determined by Griess reaction ${ }^{[27]}$ using Biodiagnostic-Egypt Nitrite Assay Kit. Total antioxidant capacity (TAC) was measured spectrophotometrically by colorimetric chemical method (BioDiagnostic-Egypt) ${ }^{[28]}$.

\section{- Myeloperoxidase assessment:}

MPO enzyme, a marker for neutrophil infiltration, is determined indirectly based on its ability to reduce hydrogen peroxide according to the chemical colorimetric method of Krawisz et al. ${ }^{[29]}$ by using MPO Assay Kit (Elabscience Biotechnology Inc. China).

The protein content in colonic and kidney tissue homogenates was determined by Lowry method; using bovine serum albumen as a protein standard ${ }^{[30]}$.

\section{Statistical analysis:}

All numeric data obtained are expressed as mean \pm SDM. One-way analysis of variance (ANOVA) was used to compare between groups, followed by Tukey post test. $\mathrm{P}$-values of $<0.05$ were considered statistically significant. The analysis was performed by using GraphPad Prism software, version 5 (CA, USA).

\section{RESULTS}

All subgroups of the control rats (negative control, vehicle 1 and 2) had no significant differences between them in clinical, macroscopic, histological and biochemical findings. Therefore, only the findings of the negative control were reported as a control group.

\section{Colon Results}

\section{Clinical and macroscopic results:}

Rats in AA-colitis group had significant weight loss by the end of experiment ( $>16 \%$ from baseline). This group also had significantly higher DAI, macroscopic scores, increased colon wet weight/length ratio, as a marker of colon inflammation than normal controls . Administration of RP or ATRA in groups III and IV led to significant increase in body weight and amelioration of DAI with significant reductions in mean macroscopic scores and colon wet weight/length ratio when compared to colitis group (Table 1).

\section{Histological and biochemical results:}

H\&E examined sections of control colon showed intact mucosa with their lining epithelium and intestinal glands. Ulcerative colitis group revealed disrupted crypts, sloughing of surface epithelium and cellular infilteration (Figs 1a,b)

In animals with AA-colitis, colon leukocyte infiltration was associated with significant higher levels of MPO than controls. Marked increase in the colonic inflammatory response indicated by significant increases in colonic tissue levels of proinflammatory cytokine TNF- $\alpha$, the transcription factor NF- $\kappa \mathrm{B}$, along with significant increase in the level of the angiogenic factor VEGF-A when compared to controls. Both RP and ATRA significantly diminished tissue levels of MPO, TNF- $\alpha$, NF- $\kappa B$ and VEGF-A when compared to colitis model. However ATRA provide better effect in normalizing theses parameters to control levels than in RP treated animals that still have significantly higher levels of TNF- $\alpha$, NF- $\kappa$ B and VEGF-A than controls (Table 2).

Regarding oxidative stress markers, administration AA led to significant increments of colonic MDA and total nitrite, with significant reduction in colonic mucosal antioxidant defenses in the form of decreased colon TAC when compared to control group. Both RP and ATRA administration suppressed the oxidative stress evident by significant reduction in colonic tissue levels of MDA and total nitrite with significant elevation of colon TAC level compared to levels observed in group II. ATRA treatment is more efficacious than RP treatment in group III that still has significant differences from control animals in these parameters (Table 2).

\section{Kidney results:}

\section{Histological and biochemical results:}

Histological examination of the control group showed the normal structure of the renal corpuscle; glomeruli and Bowman's capsule with visceral and parietal layers enclosing Bowman's space (Fig.2a). Normal proximal and distal tubules appeared with fine intertubular collagen fibers and around renal glomeruli (Fig.2b). Negative 
Immunoperoxidase reaction for Bax was obsereved (Fig. 2c) with normal ultrastructure regarding podocytes, glomerular capillaries and the glomerular filtration barrier. Also, The proximal and distal convoluted tubules revealed normal appearance of luminal border and Basal infoldings (Figs.2d,e,f). These structural findings confirmed by normal biochemical assays.

Intracolonic administration of AA (group II) caused acute kidney injury observed by structural alteration in renal cortex that showed congested glomerular and peritubular capillaries, irregular parietal layer of Bowman's capsule and ill-defined Bowman's space(Figs.3a). This renal damage was confirmed by significant elevation in serum levels of creatinine and urea as compared to controls (Table 3). Marked congestion of blood vessels, hyalinization and cellular infilteration of same group (Fig.3b) that confirmed by significant elevation of tissue levels of the angiogenic factor VEGF-A and all inflammatory markers as compared to control (Table 3).

Mallory trichrome stained sections of same group (II) showed increased collagen fibers around renal glomerular endothelium, in the pritubular interstitial tissue and around interstitial blood vessels (Fig. 3c).Also, strong Bax immunoreaction(Fig. 3d) detected and confirmed biochemically by increased all oxidative stress markers (Table 3). Ultrastructuraly, distorted podocyte foot processes, glomerular filtration barrier and thickened glomerular basement membrane were detected (Fig. 3e). Proximal convoluted tubular cells had distorted apical microvilli, irregular distribution of basal mitochondria, irregular basal infoldings, intracytoplasmic vacuolation and electron dense bodies (Fig. 3f). Distal convoluted tubular cells also showed irregular mitochondrial distribution with wide intercellular spaces (Fig. 3g).

These changes were attenuated in RP- treated groups (III) that revealed some improvement in structure involving relatively normal histological structure of renal glomeruli and Bowman's capsule. The proximal and distal convoluted tubular cells retained some apoptotic ones (Fig. 4a). Peritubular interstitial tissue still showed some collagen fibers (Fig.4b). Strong Bax positive immunoreaction in the cytoplasm of some renal tubular cells was seen with moderate one in glomerular endothelial cells (Fig. 4c). These finding confirmed by significant elevation of oxidative stress and inflammatory markers from group II. Ultrastructural examination of same group notified the filtration barrier with regular glomerular basement membrane, fenestrated endothelium, secondary foot processes and filtration slit membrane. Some capillaries appeared congested (Fig. 4d). Their tubular structure still had same changes as group II (Fig. 4 e,f). These changes attenuated by RP that caused significant reduction of the tested inflammatory biomarkers; TNF- $\alpha, N F-\kappa B$, MPO VEGF-A and oxidative stress markers levels in renal tissue when compared to AA-colitis group but within limits (Table 3).

ATRA supplementation inhibited the observed oxidative stress in kidney where significant reduction in renal tissue levels of MDA and total nitrite with significant elevation of kidney TAC level compared to those observed in colitis model (Table 2,3). It is worthy noted that the effect of ATRA was more efficacious than RP as it caused significant differences from control animals in all biochemical parameters. Lower levels of TNF- $\alpha$ and NF- $\kappa \mathrm{B}$ were also detected with ATRA than PR treated group (Table 3).

Light microscopic examination of ATRA-treated group(IV) showed apparently normal structure of renal cortex and proximal and distal convoluted tubules (Fig. 5a). Few intertubular collagen fibers and faint Bax immunoreaction were detected (Fig. 5b,c). The ultrastructure of same group revealed more improvement in glomerular and tubular structure (Fig. 5d,e,f) than PR-treated group that reflect the biochemical difference between the two groups.

Table 1: Percent changes in body weight, disease activity index (DAI), macroscopic scores and colon wet weight/length ratio in experimental groups

\begin{tabular}{|c|c|c|c|c|}
\hline & $\begin{array}{c}\text { Group I (Control) } \\
\qquad(\mathrm{n}=6)\end{array}$ & $\begin{array}{l}\text { Group II (AA- } \\
\text { colitis) }(\mathrm{n}=6)\end{array}$ & $\begin{array}{l}\text { Group III (RP- } \\
\text { treated) }(\mathrm{n}=6)\end{array}$ & $\begin{array}{l}\text { Group IV(ATRA } \\
\text { - treated) }(\mathrm{n}=6)\end{array}$ \\
\hline$\%$ change of body weight & $4.03 \pm 3.37$ & $-16.67 \pm 2.49^{* * *}$ & $-9.07 \pm 2.02^{* * *, \dagger \dagger}$ & $-5.02 \pm 4.09^{* * *,+\dagger \dagger}$ \\
\hline DAI (Score: 0-12) & $00 \pm 00$ & $5.83 \pm 1.17^{* * *}$ & $3.33 \pm 0.52^{* * *, \dagger \dagger}$ & $2.17 \pm 0.98^{* * *, \dagger \dagger \dagger}$ \\
\hline macroscopic damage (score: $0-10$ ) & $00 \pm 00$ & $6.17 \pm 1.17^{* * *}$ & $2.5 \pm 0.55^{* * *, \dagger \dagger}$ & $2.17 \pm 0.75^{* * *,+\dagger \dagger}$ \\
\hline colon weight/length ratio $(\mathrm{mg} / \mathrm{cm})$ & $102.9 \pm 7.79$ & $173.1 \pm 18.57^{* * *}$ & $128.2 \pm 18.22^{*, \dagger \dagger \dagger}$ & $116.2 \pm 11.39^{*},+\pi \dagger$ \\
\hline
\end{tabular}

AA, acetic acid; RP, retinyle palmitate; ATRA, all-trans retinoic acid. Data are expressed as the mean \pm SD. $* P<0.05,{ }^{* * *} P<0.001$ vs group I. $\dagger \dagger P<0.01, \dagger \dagger P<0.001$ vs group II. 
Table 2: Colon tissue concentration of MPO, TNF- $\alpha, \mathrm{NF}-\kappa \mathrm{B}, \mathrm{VEGF}-\mathrm{A}, \mathrm{MDA}$, total nitrite, TAC in experimental groups

\begin{tabular}{|c|c|c|c|c|}
\hline & $\begin{array}{l}\text { Group I (Control) } \\
\qquad(\mathrm{n}=6)\end{array}$ & $\begin{array}{c}\text { Group II (AA- colitis) } \\
\qquad(\mathrm{n}=6)\end{array}$ & $\begin{array}{l}\text { Group III (RP- } \\
\text { treated) }(n=6)\end{array}$ & $\begin{array}{l}\text { Group IV(ATRA- } \\
\text { treated) }(\mathrm{n}=6)\end{array}$ \\
\hline MPO (U/g tissue) & $2.14 \pm 1.52$ & $9.79 \pm 3.93^{* * *}$ & $5.03 \pm 1.62^{\dagger}$ & $3.96 \pm 2.78^{\dagger \dagger}$ \\
\hline TNF- $\alpha(\mathrm{Pg} / \mathrm{mg}$ protein $)$ & $6.12 \pm 1.04$ & $18.26 \pm 3.94^{* * *}$ & $12.9 \pm 3.67^{* *, \dagger, \ddagger}$ & $7.71 \pm 2.83^{\dagger \dagger}$ \\
\hline $\mathrm{NF}-\kappa \mathrm{B}$ (ng/100mg tissue) & $31.18 \pm 8.37$ & $59.91 \pm 10.51^{* * *}$ & $45.77 \pm 8.89^{*}, \dagger$ & $38.11 \pm 3.42^{\dagger \dagger}$ \\
\hline VEGF-A (Pg/mg tissue) & $13.3 \pm 3.16$ & $26.35 \pm 5.2^{* * *}$ & $20.05 \pm 3.32^{*, \dagger}$ & $15.79 \pm 3.54^{\dagger \dagger}$ \\
\hline MDA (n mol/mg protein) & $5.52 \pm 1.47$ & $20.15 \pm 5.51^{* * *}$ & $12.71 \pm 2.79^{*}, \dagger$ & $8.86 \pm 3.01^{\dagger \dagger}$ \\
\hline Total nitrite $(\mu \mathrm{mol} / \mathrm{mg}$ protein $)$ & $14.46 \pm 3.36$ & $28.64 \pm 4.6^{* * *}$ & $21.31 \pm 2.38^{*}, \dagger$ & $17.48 \pm 4.57^{\dagger \dagger}$ \\
\hline TAC (n mol/mg protein) & $120.8 \pm 19.71$ & $70.55 \pm 17.81^{* * *}$ & $96.38 \pm 9.81^{*, \dagger}$ & $105.1 \pm 7.17^{\dagger \dagger}$ \\
\hline
\end{tabular}

MPO, myeloperoxidase; TNF- $\alpha$, tumer necrosis factor-alpha; NF- $\mathrm{kB}$, nuclear factor kappa B; VEGF-A, vascular endothelial growth factor-A; MDA, malondialdehyde; TAC, total antioxidant capacity; AA, acetic acid; RP, retinyle palmitate; ATRA, all-trans retinoic acid. Data are expressed as the mean \pm SD. $* P<0.05$, $* * P<0.01, * * * P<0.001$ vs group I. $\uparrow P<0.05, \uparrow \uparrow P<0.01, \uparrow \dagger+P<0.001$ vs group II, $\$ P<0.05$ vs group IV

Table 3: Serum urea, creatinine levels and renal tissue concentration of MPO, TNF- $\alpha$, NF- $\kappa B$, VEGF-A, MDA, total nitrite, TAC and Bax optical density in experimental groups

\begin{tabular}{|c|c|c|c|c|}
\hline & Group I (Control) $(\mathrm{n}=6)$ & $\begin{array}{l}\text { Group II } \quad(\text { AA colitis }) \\
(\mathrm{n}=6)\end{array}$ & Group III (RP) (n=6) & $\begin{array}{l}\text { Group } \text { IV(ATRA } \\
\text { treated) }(\mathrm{n}=6)\end{array}$ \\
\hline Urea $(\mathrm{mg} / \mathrm{dl})$ & $27.08 \pm 6.24$ & $42.85 \pm 3.81^{* * *}$ & $33.73 \pm 4.74^{\dagger}$ & $31.05 \pm 4.52^{\dagger \dagger}$ \\
\hline Creatinine (mg/dl) & $0.64 \pm 0.21$ & $1.21 \pm 0.1^{* * *}$ & $0.94 \pm 0.12^{*, \dagger}$ & $0.74 \pm 0.14^{\dagger \dagger}$ \\
\hline MPO (U/g tissue) & $5.04 \pm 1.68$ & $13.71 \pm 3.22^{* * *}$ & $9.32 \pm 2.15^{*, \dagger}$ & $7.1 \pm 2.08^{\dagger \dagger \dagger}$ \\
\hline TNF- $\alpha$ (Pg/mg protein $)$ & $1.59 \pm 1.15$ & $15.33 \pm 3.39^{* * *}$ & $5.71 \pm 2.18^{*}$, 柿, & $2.22 \pm 0.88^{\dagger \dagger \dagger}$ \\
\hline NF- $\kappa B$ (ng/100mg tissue) & $17.49 \pm 1.85$ & $34.99 \pm 5.59^{* * *}$ & $26.69 \pm 3.97^{* *, \dagger+, *}$ & $20.11 \pm 3.13^{\dagger \dagger \dagger}$ \\
\hline VEGF-A (Pg/mg tissue) & $71.16 \pm 16.03$ & $134.1 \pm 13.48^{* * *}$ & $107.2 \pm 13.82^{* *, \dagger}$ & $95.03 \pm 20.02^{\dagger \dagger}$ \\
\hline MDA (n mol/mg protein) & $2.8 \pm 0.63$ & $6.75 \pm 1.03^{* * *}$ & $4.92 \pm 1.02^{*, \dagger}$ & $3.61 \pm 1.63^{\dagger \dagger}$ \\
\hline $\begin{array}{l}\text { Total nitrite }(\mu \mathrm{mol} / \mathrm{mg} \\
\text { protein) }\end{array}$ & $4.52 \pm 1.13$ & $11.76 \pm 2.46^{* * *}$ & $7.81 \pm 1.49^{*}, \dagger$ & $5.54 \pm 2.28^{+\dagger \dagger}$ \\
\hline TAC (n mol/mg protein) & $133.8 \pm 22.8$ & $72.92 \pm 14.5^{* * *}$ & $100.3 \pm 11.73^{*, \dagger}$ & $109.9 \pm 14.83^{\dagger \dagger}$ \\
\hline Bax optical density & $55.4 \pm 18.33$ & $142.4 \pm 29.31^{* * *}$ & $101.8 \pm 28.13^{*}, \dagger$ & $73.74 \pm 22.53^{\dagger \dagger \dagger}$ \\
\hline
\end{tabular}

MPO, myeloperoxidase; TNF- $\alpha$, tumor necrosis factor-alpha; NF- $\kappa \mathrm{B}$, nuclear factor kappa B; VEGF-A, vascular endothelial growth factor-A; MDA, malondialdehyde; TAC, total antioxidant capacity; AA, acetic acid; RP, retinyle palmitate; ATRA, all-trans retinoic acid. Data are expressed as the mean \pm SD. $* P<0.05, * * P<0.01, * * * P<0.001$ vs group I. $\uparrow P<0.05, \dagger \uparrow P<0.01, \dagger \dagger \uparrow P<0.001$ vs group II. $\ddagger P<0.05$ vs group IV. 


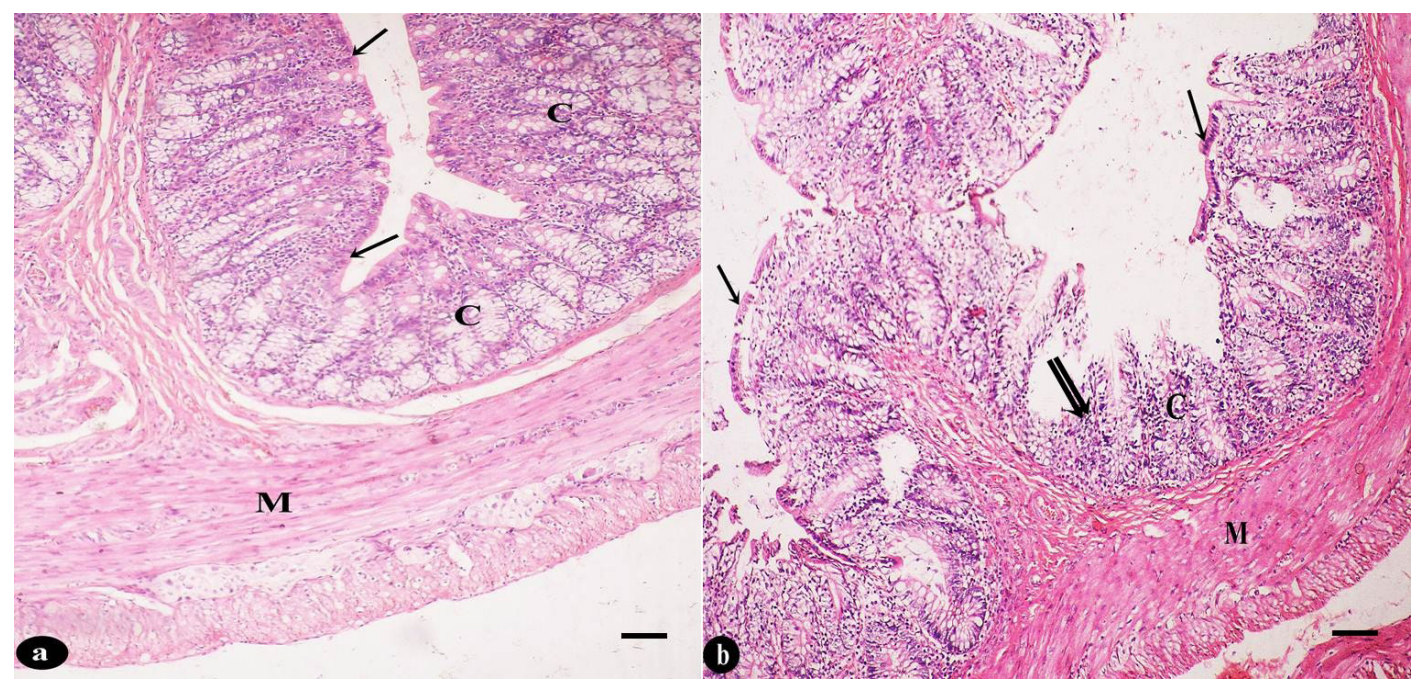

Fig. 1: (a) Photomicrograph of H\&E stained sections of control rat colon showing the intact mucosa with their lining epithelium (arrow) and intestinal glands (c). (b) Ulcerative colitis group showing disrupted crypts (c), sloughing of surface epithelium (arrow) and cellular infilteration (double arrow). Notice, normal Musculosa (M). (H\&E $\times 100$, scale bar $50 \mu \mathrm{m})$

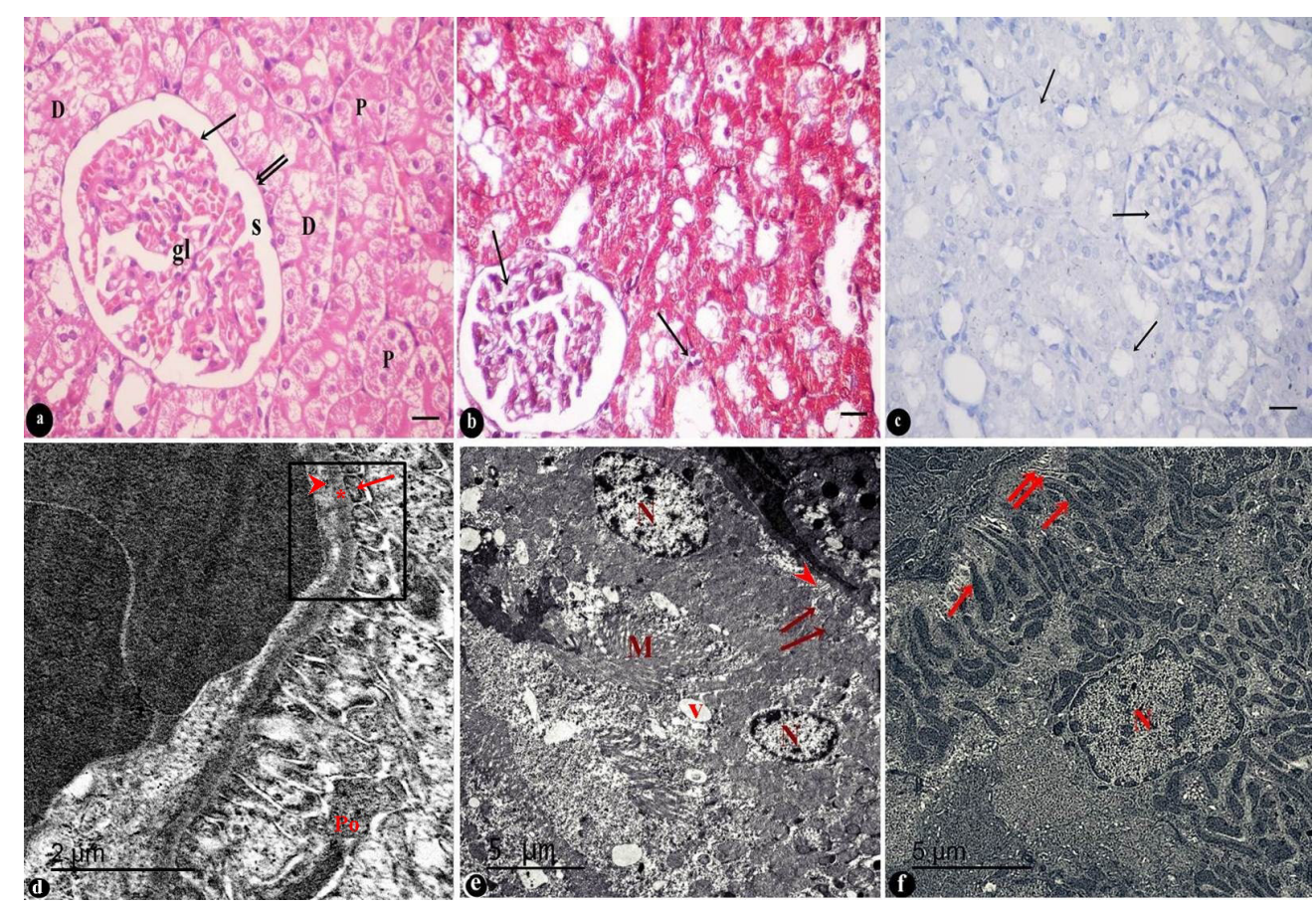

Fig. 2: (a) Control renal cortex showing renal glomeruli (gl) and Bowman's capsule consisting of visceral (arrow) and parietal layers (double

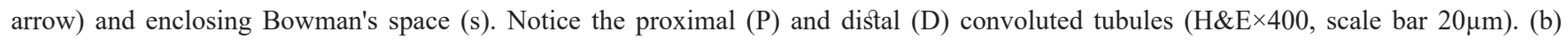
Fine collagen fibers (arrow) in interstitial tissue between renal tubules and glomerular pericapillary (Mallory trichrome $\times 400$, scale bar $20 \mu \mathrm{m}$ ). (c) Notice, negative immunoreaction (arrow) in cytoplasm of glomerular endothelium and renal tubular cells (Immunoperoxidase technique $\times 400$, scale bar $20 \mu \mathrm{m}$ ). (d) Podocytes ( $\mathrm{Po}$ ) with their foot processes and glomerular capillaries are lined by fenestrated endothelium (arrowhead). Glomerular filtration barrier is formed of regular basement membrane $(*)$, fenestrated endothelium and secondary foot processes with the filtration slit membrane (arrow) (TEM, scale bar $2 \mu \mathrm{m}$ ). (e) Proximal convoluted tubular cells are noticed with euchromatic nuclei $(\mathrm{N})$, luminal microvilli (M) and apical pinocytotic vesicles (v). Basal infoldings (arrow head) and basal mitochondria (arrow) are detected. (f) Distal convoluted tubular cell with euchromatic nucleus (N), basal infoldings (double arrow) and basal mitochondria (arrow) are detected (TEM, scale bar $5 \mu \mathrm{m}$ ) 


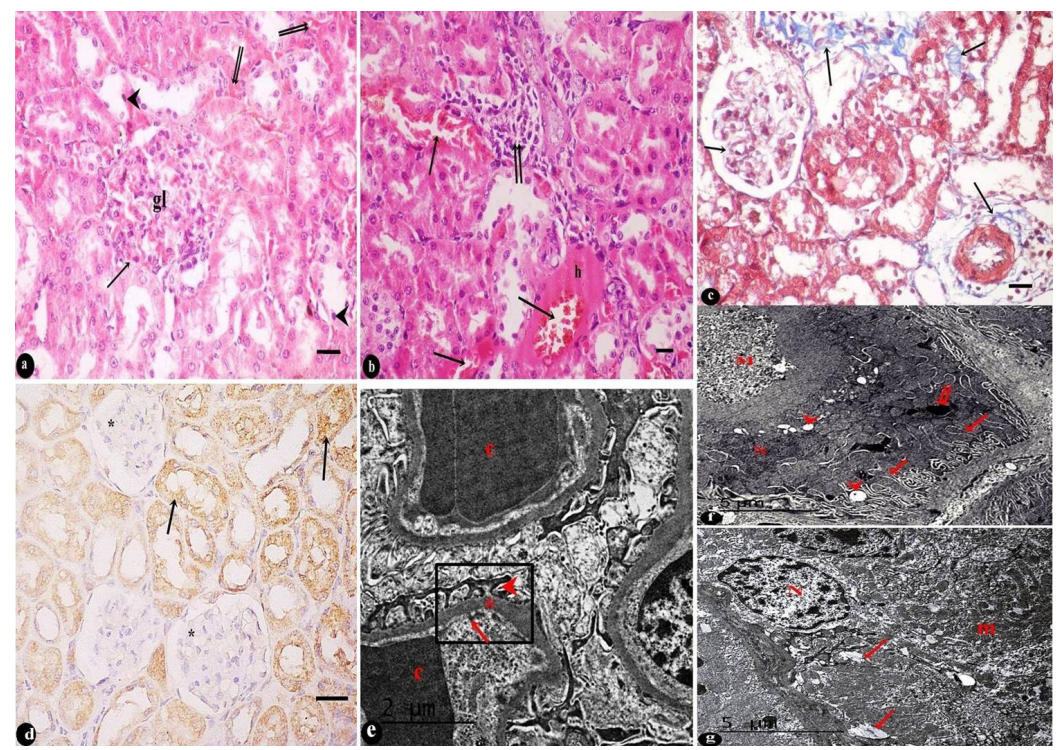

Fig. 3: (a) Induced-colitis renal cortex showing congested glomerular capillaries (gl), irregular parietal layer (arrow) of Bowman's capsule and ill-defined Bowman's space. Congested peritubular capillaries (double arrow) around renal tubules are noticed. Some renal tubular cells are lined by small apoptotic nuclei (arrow head). (b) shows Marked congestion of blood vessels (arrow), hyalinization (h) and cellular infilteration (double arrow) $(H \& E \times 400$, scale bar $20 \mu \mathrm{m})$. (c) Increased collagen fibers is noticed (arrow) around renal glomerular capillaries, intertubular interstitial tissue and around blood vessels (Mallory trichrome $\times 400$, scale bar $20 \mu \mathrm{m}$ ). (d) Strong positive reaction (arrow) in the cytoplasm of renal tubular cells and some glomerular endothelium $\left(^{*}\right)$ (Immunoperoxidase technique $\times 400$, scale bar $20 \mu \mathrm{m}$ ). (e) Notice, glomerular capillaries (c), distorted podocyte foot processes (arrow head), glomerular filtration barrier (arrow) and thickened glomerular basement membrane $(*)$ (TEM, scale bar $2 \mu \mathrm{m}$ ). (f) Proximal convoluted tubular cells with distorted apical microvilli (M), irregular distribution of basal mitochondria (m), irregular basal infoldings (arrow), intracytoplasmic vacuolation (arrow head) and electron dense bodies (double arrow). (g) Distal convoluted tubular cells with euchromatic nuclei $(\mathrm{N})$, irregular mitochondrial distribution (m), wide intercellular spaces (arrow) (TEM, scale bar $5 \mu \mathrm{m}$ )

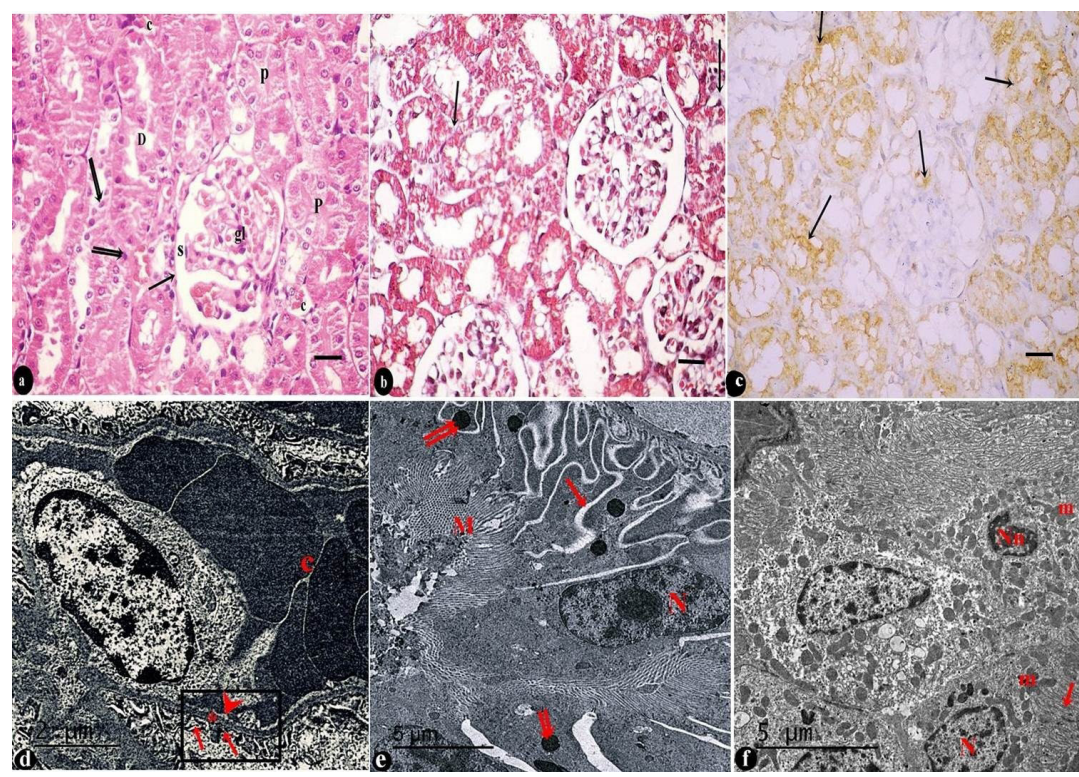

Fig. 4: (a) Retinyle palmitate-treated group with apparently normal renal cortex with glomeruli (gl) and Bowman's capsule of visceral and parietal (arrow) layers that preserved with its Bowman's space (s). Proximal (P) and distal (D) convoluted tubular cells have vesicular nuclei except some apoptotic ones (double arrow) (H\&E $\times 400$, scale bar $20 \mu \mathrm{m}$ ). (b) Some collagen fibers (arrow) in intertubular tissue still detected (Mallory trichrome $\times 400$, scale bar $20 \mu \mathrm{m}$ ). (c) Moderate immunoreaction in cytoplasm of both renal tubular and glomerular endothelial cells (arrow) are showed. (Immunoperoxidase technique $\times 400$, scale bar $20 \mu \mathrm{m}$ ). (d) Renal cortex reveals glomerular capillaries lined by fenestrated endothelium (arrow head). Glomerular filtration barrier with regular glomerular basement membrane $(*)$, fenestrated endothelium and secondary foot processes (arrow) with the filtration slit membrane. Notice, some congested capillaries(c) (TEM, scale bar $2 \mu \mathrm{m})$. (e) Proximal convoluted tubular cells with euchromatic nuclei (N), luminal microvilli (M), electron dense bodies (double arrow), and irregular basal infoldings (arrow). (f) The distal convoluted tubular cells have euchromatic nuclei (N) but others have heterochromatic (Nn) ones. Basal infoldings (arrow) and basal mitochondria (m) are also seen (TEM, scale bar $5 \mu \mathrm{m}$ ) 


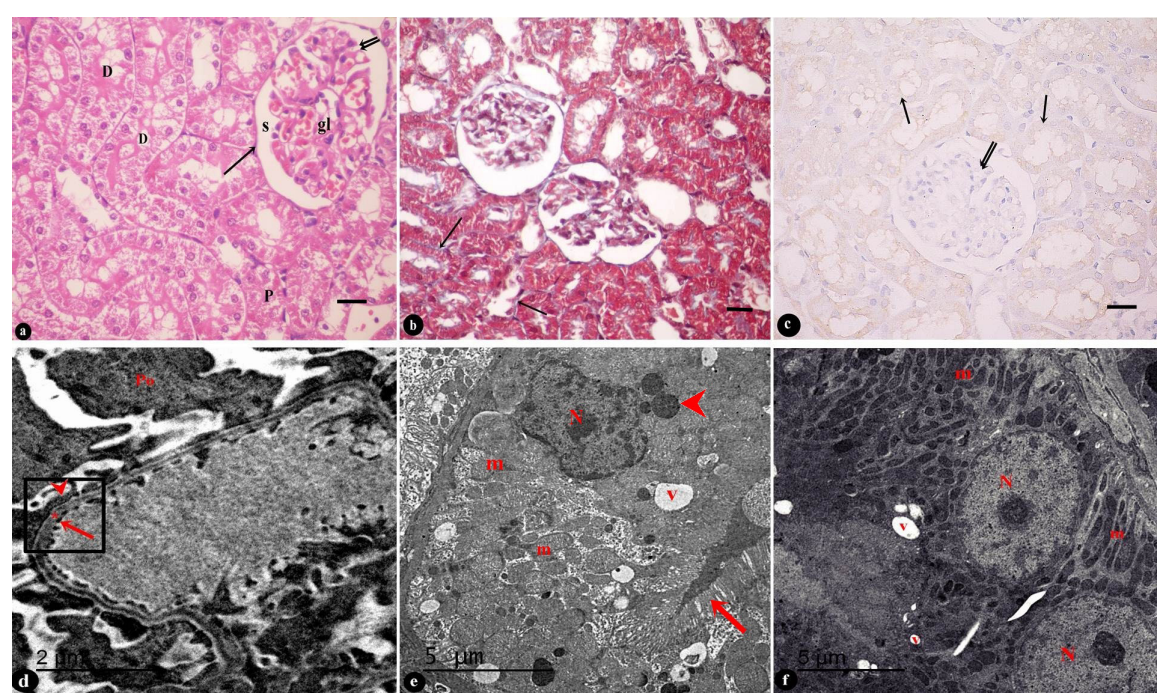

Fig. 5: (a) All-trans retinoic-treated renal cortex showing normal renal glomeruli (gl) with visceral (double arrow) and parietal (arrow) layers enclosing Bowman's space (s) and Proximal (P) and distal (D) convoluted tubules (H\&E×400, scale bar 20 $\mu$ m). (b) Few collagen fibers (arrow) in intertubular tissue and around glomerular endothelium (Mallory trichrome $\times 400$, scale bar $20 \mu \mathrm{m}$ ). (c) Faint positive immunoreaction in the cytoplasm of glomerular endothelium (double arrow) and tubular cells (arrow) (Immunoperoxidase technique $\times 400$, scale bar $20 \mu \mathrm{m}$ ). (d) Normal podocytes (Po) with their foot processes, glomerular capillaries with fenestrated endothelium (arrow) and filtration barrier composed of regular glomerular basement membrane $(*)$, fenestrated endothelium and secondary foot processes (arrow head) (TEM, scale bar $2 \mu \mathrm{m}$ ). (e) Proximal convoluted tubules have euchromatic nuclei (N), luminal microvilli (arrow), apical pinocytotic vesicles (v) and electron dense bodies (arrow head). Notice, basal mitochondria (m). (f) Distal convoluted tubules have euchromatic nuclei (N), and basal infoldings enclosing basal mitochondria (m) and some vacuoles (v) (TEM, scale bar $5 \mu \mathrm{m}$ )

\section{DISCUSSION}

Ulcerative colitis is a chronic inflammatory bowel disease, resulting from colonic mucosal and submucosal damage that affects quality of $\operatorname{life}^{[2]}$. Apart from gut manifestation there are many extra-intestinal manifestations including renal involvement ${ }^{[3]}$. Kidney damage can be provoked by the disease itself or as a side effect of therapy ${ }^{[4,5]}$. The protection against renal injury early in $\mathrm{UC}$ is challenging, therefore, it is important to identify the pathophysiological mechanism of renal damage and thereafter to explore new treatment targets. To investigate for this we employed a rat model, using intracolonic instillation of $4 \%$ acetic acid to induce histopathological changes and inflammatory biomarkers that mimics the human $\mathrm{UC}^{[19,31]}$.

In this study,the colonic inflammatory response was characterized by weight loss, increase DAI, colon macroscopic damage and edema (increased colonic weight/height ratio), the histological alteration was associated with infiltration of inflammatory cell with increased tissue levels of MPO, which is an index of neutrophilic infiltration and is reflexing the degree of mucosal inflammation ${ }^{[29]}$. The increased tissue levels of TNF- $\alpha, N F-\kappa B$, in addition to enhanced lipid peroxidation and increased total nitrite with depletion of TAC confirming the role of inflammation and oxidative stress in the pathogenesis of UC in this model that fits with other models of AA-induced ulcerative colitis ${ }^{[31,32]}$.

TNF- $\alpha$ is a main cytokine involved in intestinal tract inflammation and in the development of UC, its level in colonic mucosa and serum correlate with disease activity ${ }^{[11,33]}$. TNF- $\alpha$ is a NF- $\kappa B$ dependent gene; alternatively, $\mathrm{TNF} \alpha$ is also a potent inducer for $\mathrm{NF}-\mathrm{\kappa B}^{[34]}$. Activation of NF- $\mathrm{KB}$ is markedly induced in UC patients and strongly affects the course of mucosal inflammation and disrupting epithelial integrity via activation of genes involved in inflammation, immunity and apoptosis ${ }^{[35]}$.

Oxidative stress and imbalance between oxidants and antioxidants is one of the major pathophysiological mechanisms of $\mathrm{UC}^{[32]}$. Increased inflammatory cell infiltration by acetic acid, as detected in the present study, was associated with generation of free radicals and increased lipid peroxidation that resulted in colonic tissue damage ${ }^{[36]}$. TNF- $\alpha$, could also stimulate reactive oxygen species generation that aggravate inflammation cascade ${ }^{[37]}$. In addition, oxidative stress is important in augmenting inflammation through the activation of $\mathrm{NF}-\mathrm{kB}$ and its related signaling pathways ${ }^{[38]}$.

As UC is a disease that can affect multiple extraintestinal organs, we aimed to explore the kidney as a target for UC-related systemic injury. Acute kidney injury was confirmed by increased serum urea, creatinine levels 
that were evidenced by structural changes in renal cortex, congested peritubular capillaries, cellular infiltration and increased apoptosis. The clinical relevance of our results was confirmed by describing renal tubular injury ${ }^{[7]}$ and acute interstitial nephritis unrelated to the consumption of nephrotoxic agents in UC patients ${ }^{[8]}$.

Association between UC and kidney damage is worthy noticed and investigated. In a mouse model of colitis it was shown that inflammation had a central role in mediating kidney damage ${ }^{[39]}$. In the present study, induction of colitis significantly increased renal tissue levels of TNF- $\alpha$, NF$\kappa \mathrm{B}$, increased cellular infiltration with increased tissue level of MPO indicating that inflammatory reaction was triggered in kidney tissue in the context of UC systemic effect. Hence, the role of inflammatory cross-talk between the intestine and the kidney is suggested in the pathophysiology of acute renal damage.

Many drugs are used in treatment of UC such as antiinflammatory (aminosalicylates and glucocorticosteroids), immune modulators, antibiotics and anti-TNF- $\alpha .4$ with known side effects on kidney ${ }^{[5]}$. On this basis, the development of additional safe and efficient therapy for UC and associated renal damage is a pressing need. Retinoids are biologically active agents, derivatives of VA that are found in animal-sourced foods, such as oily fish, liver, cheese and butter. They have broad spectrum physiological functions such as immune regulation, cell growth, differentiation, regulation of apoptosis and suppression of inflammation ${ }^{[12,13,40]}$. ATRA and RP are naturally occurring retinoids ${ }^{[13,41]}$. Retinyl esters such as RP are dietary forms of VA that is absorbed from intestine and is enzymatically activated to the biologically active metabolite, retinoic acid via a two-step oxidation process ${ }^{[41]}$. The all-trans retinoic acid is the metabolic form that is transcriptionally active retinoids within cells and tissues in vivo ${ }^{[15,41]}$. Retinoids are characterized by their tendency to activate cytosolic retinoic acid receptors, which heterodimerizes with retinoid $\mathrm{X}$ receptors, leading to stimulating the transcription of the retinoic acid response element on target genes ${ }^{[41]}$. Treatment with either RP or ATRA reduced the weight loss, DAI, colon macroscopic damage and edema and attenuated renal histological alteration, leucocytic infiltration. Both diminished tissue levels of MPO, TNF- $\alpha$ and NF- $\kappa B$ in colon and kidney, suggesting that both RP and ATRA exhibited anti-inflammatory activity in ameliorating the colitis and development of acute kidney disease. In agreement with this, previous researches reported that VA deficiency exacerbated colon inflammation and delay recovery than in retinyl acetate-supplemented animals ${ }^{[14]}$ and that ATRA decreased inflammatory responses in colitis model. The anti-inflammatory protective role of ATRA on early stages of diabetic nephropathy in rats was also reported ${ }^{[17]}$. Consistent with our findings, previous data showed that the anti-inflammatory effect of retinoids might be attributed to the inhibition of NF- $\kappa \mathrm{B}$ and to the reduction of TNF- $\alpha^{[17,40,42]}$.
This study reported the role of oxidative stress in the pathogenesis of acute kidney damage. Where the results showed enhanced levels of MDA and total nitrites in renal tissues with diminished TAC. The ultrastructural renal results showed distorted podocyte foot processes, glomerular filtration barrier and thickened glomerular basement membrane. Some researchers ${ }^{[43]}$ postulated that podocytes are generally regarded as targets of oxidative stress by stimulating podocyte production of the proinflammatory cytokines that induced apoptosis in podocytes and directly injure the glomerular basement membrane. Additionally, the renal PCT cells have distorted apical microvilli, irregular distribution of basal mitochondria, irregular basal infoldings, intracytoplasmic vacuolation and electron dense bodies. The distal convoluted tubular cells revealed irregular mitochondrial distribution, wide intercellular spaces. These results are in consistent with previous report that indicated oxidative stress in injured tubular epithelium can induce perturbations of the cytoskeleton structure and function ${ }^{[4]}$.

In the current study, both retinoids combated oxidative stress and boosted the antioxidant status in colonic and renal tissue which was evidenced by reduction of MDA and total nitrite in addition to enhancing TAC tissue levels. These findings agree with previous results that reinforce the antioxidant effect of retinoids ascribed to increased antioxidant enzymes in inflammatory condition ${ }^{[45]}$.

In UC-induced group, some tubular cells were lined by small apoptotic nuclei with marked congestion of blood vessels, hyalinization and cellular infilteration with evident increase in collagen fibers. Some researchers reported related pathological changes including apoptosis, inflammatory cell infiltration, and increased collagen tissue in different organs accompanying $\mathrm{UC}^{[46]}$.

In this study, colitis increased the number of apoptotic cells in rat kidneys, confirmed by strong Bax immunoreaction. Bax is a class of genes that can promote apoptosis through the regulation of cytokines ${ }^{[47]}$. Increased apoptosis may be due to the observed oxidative stress since excessive exposure of renal tissue to oxidative stress under inflammatory stimuli enhances apoptosi ${ }^{[48]}$. In the present study, RP and ATRA markedly diminished the apoptosis in renal tubules that showed reduction in apoptoyic cells and immunohistchemical staining of BAX. These findings are consistent with previous reports that described the inhibition of retinoids for apoptosis in myocardial ischemia/reperfusion injury and neuronal cells ${ }^{[49,50]}$. The attenuation of renal apoptosis can be attributed to the observed reduction of oxidative stress ${ }^{[48]}$.

In this study, VEGF-A colonic and renal tissue levels increased in colitis group. VEGF-A, a principle mediator of angiogenesis in $\mathrm{UC}$, has been found to be increased in UC that results in inflamed blood vessels that increase disease activity and progression ${ }^{[51,52]}$. The current results showed 
clear angiogenesis in kidney in the form of congested glomerular and peritubular capillaries suggesting that the pathological angiogenesis might have also played a role in the pathophysiology of initial renal changes. A previous study reported that TNF- $\alpha$ can trigger angiogenesis and induce pathological changes within the lung in an experimental model of colitis ${ }^{[52]}$. It was also reported that NF- $\kappa B$ promoted the expression of VEGF-A and enhances angiogenesis ${ }^{[53]}$. In this study, RP and ATRA decreased the tissue levels of VEGF-A and attenuated the pathological angiogenesis observed in kidney. This effect is likely to be associated with the direct anti-angiogenic mechanisms of retinoids ${ }^{[54]}$. Furthermore, as we observed, the two retinoids significantly decline tissue levels of TNF- $\alpha$ and NF- $\kappa$ B which might contribute to this anti-angiogenic effect ${ }^{[52,53]}$.

Given that oral vitamin A-palmitate is preferred to be used clinically based on its stability and safety compared to retinoic acid ${ }^{[55]}$, the overall results, however, demonstrated that supplementation of ATRA can produce effects superior to those of RP. This was evident in reducing inflammation, oxidative stress, apoptosis and pathological angiogenesis in biochemical markers and related histological findings that showed mild improvement of ultrastructure in RP group with persistent irregular basal infolding in PCT with heterchromatic nuclei in DC tubular cells. This could be explained by the possibility of malabsorption of RP after oral administration. Consistent with this, decreased serum levels of retinoids was reported in UC that could be due to a deficiency in fat absorption irrespective to ilial involvement ${ }^{[56]}$

\section{CONCLUSION}

In conclusion, AA-induced colitis led to early renal damage that might be linked to the inflammatory and the oxidative stress systemic effects of colitis. RP and ATRA supplementation were effective in ameliorating early inflammatory process in colitis and its induced renal damage which might be attributed, in part, to antiinflammatory mechanism by inhibiting NF- $\mathrm{kB}$ and reducing tissue damage by antioxidant, antiangiogenic properties. Moreover, ATRA showed effects superior to those of RP. Further studies are required to explore the long term use of retinoids as a new type of adjuvant agents with conventional drugs for UC to verify the best strategy for treatment of colitis and colitis-related renal complications.

\section{ABBREVIATIONS}

UC - ulcerative colitis

AA - acetic acid

$\mathrm{RP}$ - retinyle palmitae

ATRA - all-trans retinoic acid

TNF- $\alpha$ - tumor necrosis factor-alpha

$\mathrm{NF}-\mathrm{\kappa B}$ - nuclear factor kappa-B

VEGF-A - vaoascular endothelial growth factor-A

MPO - myeloperoxidase
MDA - malondialdehyde

TAC - total antioxidant capacity

IBD-inflammatory bowel disease

VA - vitamin A

DAI - Disease activity index

PCT - proximal convoluted tubule

AEC - 3-amino 9-ethyl carbazole

\section{ACKNOWLEDGMENTS}

It is to specifically state that "there is No Conflict of Interest" with other people or organizations that could inappropriately influence or bias the content of the paper.

Also, This research did not receive any specific grant from funding agencies in the public, commercial, or notfor-profit sectors.

\section{CONFLICT OF INTEREST}

There are no conflicts of interest.

\section{REFERENCES}

1. Dulai PS, Singh S, Casteele NV, Boland BS, Sandborn WJ. How will evolving future therapies and strategies change how we position the use of biologics in moderate to severely active inflammatory bowel disease. Inflamm. Bowel Dis. 2016; 22(4):998-1009.

2. Danese S, Fiocchi C. Ulcerative colitis. N Engl J Med. 2011; 365(18):1713-25.

3. Ott C, Scholmerich J. Extraintestinal manifestations and complications in IBD. Nat. Rev. Gastroenterol. Hepatol. 2013; 10(10):585-95.

4. Corica D, Romano C. Renal involvement in inflammatory bowel diseases. J. Crohn's Colitis 2016; 10(2):226-35.

5. Curkovic I, Egbring M, Kullak-Ublick GA. Risks of inflammatory bowel disease treatment with glucocorticosteroids and aminosalicylates, in: Digestive Diseases 2013; 31(3-4):368-73.

6. Torio $\mathrm{M}$, Ishimura $\mathrm{M}$, Ohga $\mathrm{S}$, Doi $\mathrm{T}$, Utsunomiya $\mathrm{R}$, Ohkubo, K et al. Nephrolithiasis as an extraintestinal presentation of pediatric inflammatory bowel disease unclassified. J. Crohn's Colitis 2010; 4(6):674-8.

7. Fraser JS, Muller AF, Smith DJ, Newman DJ, Lamb EJ. Renal tubular injury is present in acute inflammatory bowel disease prior to the introduction of drug therapy. Aliment. Pharmacol. Ther. 2001; 15(8):1131-7. 
8. Tokuyama H, Wakino S, Konishi K, Hashiguchi A, Hayashi K, Itoh H. Acute interstitial nephritis associated with ulcerative colitis. Clin. Exp. Nephrol. 2010; 14(5):483-6.

9. Engel MA, Neurath MF. New pathophysiological insights and modern treatment of IBD. J. Gastroenterol. 2010; 45(6):571-83.

10. Geremia A, Arancibia-Cárcamo CV. Innate Lymphoid Cells in Intestinal Inflammation. Front. Immunol. 2017; 13;8:1296.

11. Park JH, Peyrin-Biroulet L, Eisenhut M, Shin JI. IBD immunopathogenesis: A comprehensive review of inflammatory molecules. Autoimmun. Rev. 2017; 16(4):416-426.

12. Raverdeau M, Mills KHG. Modulation of T Cell and Innate Immune Responses by Retinoic Acid. J. Immunol. 2014; 1;192(7):2953-8.

13. Theodosiou M, Laudet V, Schubert M. From carrot to clinic: An overview of the retinoic acid signaling pathway. Cell. Mol. Life Sci. 2010; ;67(9):1423-45.

14. Okayasu I, Hana K, Nemoto N, Yoshida T, Saegusa M, Yokota-Nakatsuma et al. Vitamin A Inhibits Development of Dextran Sulfate Sodium-Induced Colitis and Colon Cancer in a Mouse Model. Biomed Res Int. 2016; 2016:4874809.

15. Collins CB, Aherne CM, Kominsky D, Mcnamee EN, Lebsack MD, Eltzschig $\mathrm{H}$, et al. Retinoic acid attenuates ileitis by restoring the balance between T-helper 17 and $\mathrm{t}$ regulatory cells. Gastroenterology 2011; 141(5):1821-31.

16. Chen XP, Lei FY, Qin YH, Zhou TB, Jiang L, Zhao YJ, et al. The role of retinoic acid receptors in the signal pathway of all-trans retinoic acidinduced differentiation in adriamycin-induced podocyte injury. J. Recept. Signal Transduct 2014; 34(6):484-92.

17. Sierra-Mondragon E, Molina-Jijon E, NamoradoTonix C, Rodríguez-Muñoz R, Pedraza-Chaverri J, Reyes JL. et al. All-trans retinoic acid ameliorates inflammatory response mediated by TLR4/NF- $\kappa \mathrm{B}$ during initiation of diabetic nephropathy. J. Nutr. Biochem. 2018; 60:47-60.

18. Randhawa PK, Singh K, Singh N, Jaggi AS. A review on chemical-induced inflammatory bowel disease models in rodents. Korean J. Physiol. Pharmacol. 2014; 18(4):279-88.
19. Mizoguchi A. Animal models of inflammatory bowel disease. Prog Mol Biol Transl Sci 2012; 105:263-320.

20. Reifen R, Levy E, Berkovich Z, Tirosh O. Vitamin A exerts its antiinflammatory activities in colitis through preservation of mitochondrial activity. Nutrition. 2015; 31(11-12):1402-7.

21. Bai A, Lu N, Zeng $H$, Li Z, Zhou $X$, Chen $\mathrm{J}$ et al. All-Trans Retinoic Acid Ameliorates Trinitrobenzene Sulfonic Acid-Induced Colitis by Shifting Th1 to Th2 Profile. J. Interf. Cytokine Res. 2010; 30 (6) 399-406.

22. Cooper HS, Murthy SNS, Shah RS, Sedergran DJ. Clinicopathological Study Of Dextran Sulfate Sodium Experimental Murine Colitis. Lab. Investig. 1993; 69(2):238-49.

23. Tsune I, Ikejima $\mathrm{K}$, Hirose $\mathrm{M}$, Yoshikawa $\mathrm{M}$, Enomoto N, Takei Y, Sato N. Dietary glycine prevents chemical-induced experimental colitis in the rat. Gastroenterology 2003; 125(3):775-85.

24. Bancroft J, Layton C. The Hematoxylin and eosin. In: Suvarna SK, Layton C and Bancroft JD editors. Theory and Practice of histological techniques (7thed.), Churchill Livingstone of El Sevier Philadelphia 2013; Pp 172-214.

25. Goodhew P, Humphreys J, Beanland R. In: Electron Microscopy and Analysis, 3rd ed. Taylor and Francis, London, New York 2001; pp: 237-255.

26. Ohkawa H, Ohishi N, Yagi K. Assay for lipid peroxides in animal tissues by thiobarbituric acid reaction. Anal. Biochem. 1979; 95(2):351-8.

27. Sasaki S, Miura T, Nishikawa S, Yamada K, Hirasue M, Nakane A. Protective role of nitric oxide in Staphylococcus aureus infection in mice. Infect. Immun. 1998; 66(3):1017-22.

28. Koracevic D, Koracevic G, Djordjevic V, Cosic C. Method for the measurement of antioxidant activity in human fluids. J. Clin. Pathol. 2001; 54(5):356-61.

29. Krawisz JE, Sharon PW, Stenson F. Quantitative assay for acute intestinal inflammation based on myeloperoxidase activity. Assessment of inflammation in rat and hamster models. Gastroenterology 1984; 87(6):1344-50.

30. Lowry OH, Rosebrough NJ, Farr AL, Randall 
RJ. Protein measurement with the Folin phenol reagent. J. Biol. Chem. 1951; 193(1):265-75.

31. Farghaly HS, Thabit RH. 1-arginine and aminoguanidine reduce colonic damage of acetic acid-induced colitis in rats: Potential modulation of nuclear factor- $\kappa \mathrm{B} / \mathrm{p} 65$. Clin. Exp. Pharmacol. Physiol. 2014; 41(10):769-79.

32. Aleisa AM, Al-Rejaie SS, Abuohashish HM, Ola MS, Parmar MY, Ahmed MM. Pretreatment of Gymnema sylvestre revealed the protection against acetic acid-induced ulcerative colitis in rats. BMC Complement. Altern. Med. 2014 Feb 10;14:49 2014.

33. Kim JH, Lin E, Pimentel M. Biomarkers of irritable bowel syndrome. J. Neurogastroenterol. Motil. 2017; 30; 23 (1):20-26.

34. Zhang K, Kaufman RJ. From endoplasmicreticulum stress to the inflammatory response. Nature 2008; 24; 454 (7203):455-62.

35. Leotoing L, Chereau F, Baron S, Hube F, Valencia HJ, Bordereaux D, et al. A20-binding inhibitor of nuclear factor-kappaB (NF-kappaB)-2 (ABIN2) is an activator of inhibitor of NF-kappaB (IkappaB) kinase alpha (IKKalpha)-mediated NFkappaB transcriptional activity. J. Biol. Chem. 2011; 16; 286 (37):32277-88.

36. Piechota-Polanczyk A, Fichna J. Review article: The role of oxidative stress in pathogenesis and treatment of inflammatory bowel diseases. Naunyn. Schmiedebergs. Arch. Pharmacol. 2014; 387(7):605-20.

37. Blaser H, Dostert C, Mak TW, Brenner D. TNF and ROS Crosstalk in Inflammation. Trends Cell Biol. 2016; 26(4):249-261.

38. Reuter S, Gupta SC, Chaturvedi MM, Aggarwal BB. Oxidative stress, inflammation, and cancer: How are they linked? Free Radic. Biol. Med. 2010; 1 ; 49(11):1603-16.

39. Ranganathan P, Jayakumar C, Santhakumar M, Ramesh G. Netrin-1 regulates colon-kidney cross talk through suppression of IL-6 function in a mouse model of DSS-colitis. Am. J. Physiol. Physiol. 2013; 1;304 (9):F1187-97.

40. Hong K, Zhang Y, Guo Y, Xie J, Wang J, He X, $\mathrm{Lu} \mathrm{N}$, Bai A. All-trans retinoic acid attenuates experimental colitis through inhibition of NF-кB signaling. Immunol. 2014; 162 (1 Pt A) :34-40. Lett
41. Li Y, Wongsiriroj N, Blaner WS. The multifaceted nature of retinoid transport and metabolism. Hepatobiliary Surg. 2014; 3(3):126-39.

42. Rafa H, Benkhelifa S, Aityounes S, Saoula H, Belhadef S, Belkhelfa M et al. All-Trans Retinoic Acid Modulates TLR4/NF- B Signaling Pathway Targeting TNF- $\alpha$ and Nitric Oxide Synthase 2 Expression in Colonic Mucosa during Ulcerative Colitis and Colitis Associated Cancer. Mediators Inflamm. 2017;2017: 7353252.

43. Tipping P. Are Podocytes Passive or Provocative in Proteinuric Glomerular Pathology? J Am Soc Neprol. 2008; 19(4):651-3 .

44. Moeckel GW. Pathologic Perspectives on Acute Tubular Injury Assessment in the Kidney Biopsy. Semin. Nephrol. 2018; 38(1):21-30

45. Mizee MR, Nijland PG, Van der Pol SM, Drexhage JA, van Het Hof B, Mebius R. et al. Astrocytederived retinoic acid: a novel regulator of bloodbrain barrier function in multiple sclerosis. Acta Neuropathol. 2014; 128 (5):691-703.

46. Liu Y, Wang XY, Yang X, Jing S, Zhu L, Gao SH. Lung and intestine: A specific link in an ulcerative colitis rat model. Gastroenterol. Res. Pract. 2013; 2013:124530.

47. Becker C, Watson AJ, Neurath MF. Complex roles of caspases in the pathogenesis of inflammatory bowel disease. Gastroenterology 2013; 144(2):283-93.

48. Hua W, Huang HZ, Tan LT, Wan JM, Gui HB, Zhao L. et al. CD36 mediated fatty acid-induced podocyte apoptosis via oxidative stress. PLoS One 2015; 10(5):e0127507.

49. Zhu Z, Zhu J, Zhao X, Yang K, Lu L, Zhang F, Shen W, Zhang R. All-trans retinoic acid ameliorates myocardial ischemia/reperfusion injury by reducing cardiomyocyte apoptosis. PLoS One 2015; 17;10 (7): 1-15

50. Zhang X, Yu Q, Jiang W, Bi Y, Zhang Y, Gong M. et al. All-trans retinoic acid suppresses apoptosis in PC12 cells injured by oxygen and glucose deprivation via the retinoic acid receptor $\alpha$ signaling pathway. Mol. Med. Rep. 2014; 10(5):2549-55

51. Cromer WE, Ganta CV, Patel M, Traylor J, Kevil CG, Alexander JS, Mathis JM. VEGF-A isoform modulation in an preclinical TNBS model of ulcerative colitis: Protective 
effects of a VEGF164b therapy. J. Transl. Med. 2013; 11;11: 207.

52. Aydin B, Songur Y, Songur N, Aksu O, Senol A, Metin Ciris I, Sutcu R. Investigation of pulmonary involvement in inflammatory bowel disease in an experimental model of colitis. Korean J. Intern. Med. 2016 ;31(5):853-9.

53. Nam SY, Ko YS, Jung J, Yoon J, Kim YH, Choi YJ. et al. A hypoxia-dependent upregulation of hypoxia-inducible factor-1 by nuclear factor-B promotes gastric tumour growth and angiogenesis. Br. J. Cancer 2011; 4;104(1):166-74.

54. Siddikuzzaman V, Grace MB. Antioxidant potential of all-trans retinoic acid (ATRA) and enhanced activity of liposome encapsulated ATRA against inflammation and tumor-directed angiogenesis. Immunopharmacol. Immunotoxicol. 2013; 35(1):164-73.

55. Surman SL, Jones BG, Sealy RE, Rudraraju R, Hurwitz JL. Oral retinyl palmitate or retinoic acid corrects mucosal IgA responses toward an intranasal influenza virus vaccine in vitamin A deficient mice. Vaccine 2014; 7;32(22):2521-4.

56. Verma P, Subodh S, Tiwari V, Rampal R, Tuteja A, Toteja GS. et al. Correlation of Serum Vitamin A Levels with Disease Activity Indices and Colonic IL-23R and FOXP3 mRNA Expression in Ulcerative Colitis Patients. Scand. J. Immunol. 2016; 84(2):110-7. 
الملخص العربى

\title{
دراسة نسيجية وكيميائية لقشرة الكلى للجرذان في التهاب القولون التقرحي المستحدث مع تقييم الدور المحتمل للريتينويدات في التهاب التون
}

\author{
داليا عبد المعين محمد2132 ، سماح محمد أحمد13 ، منال كمال3،

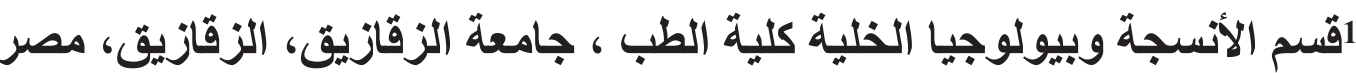 \\ 2قسم الأنسجة كلية الطب - جامعة القسيم، السعودية \\ 3قسم الفسيولوجيا الطبيه، كليه الطب، جامعة أسيوط، أسيوط، مصرئ الطبه

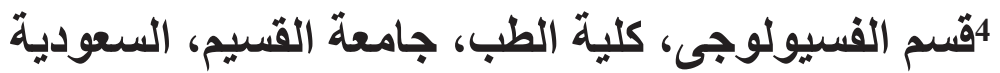

المقدمة:التهاب القولون التقرحي (UC) هو مرض الألتهاب المزمن في القولون وقد وجد انه يؤثر على أعضاء أخرى خارج الأمعاء ، مثل الكلى. الكاب.

الههدف: هدفت هذه الدر اسة إلى تقييم تأثير التهاب القولون التقرحي المحدث بحمض الأسيتيك على الكلى ودراسة التأثير المضاد

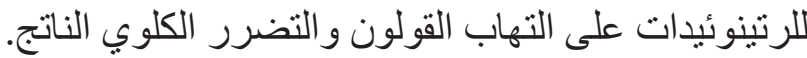
الطرق والمواد المستخدمة: تم تقسيم عدد 42 جرذا أبيض إلى: المجموعة الأولى (الضابطة) ، المجموعة الثانية (التئية (التهاب

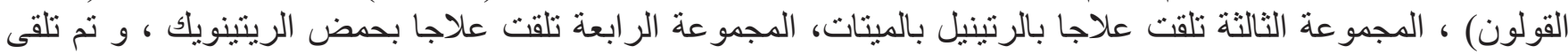

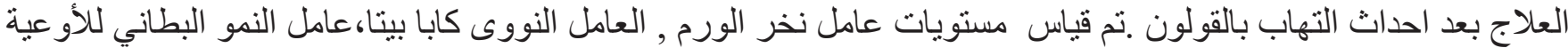

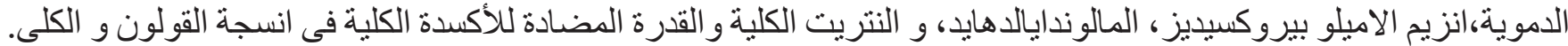

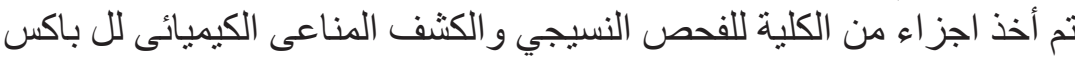

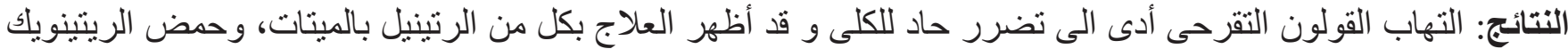

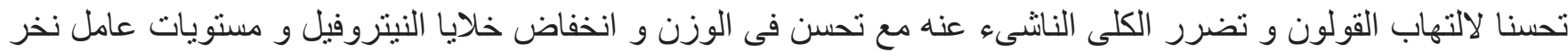

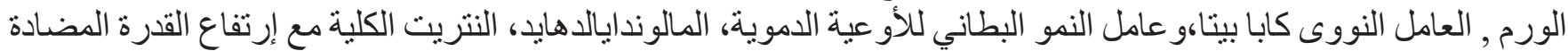

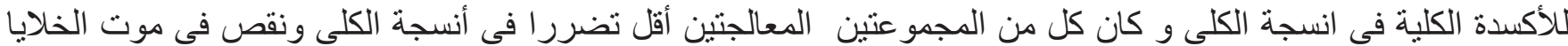
المبرمج.

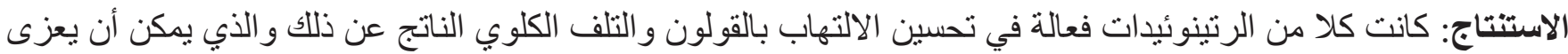

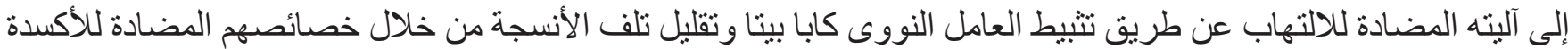

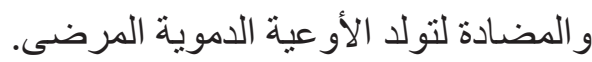

